leading to the conversion symptom is that of a woman desiring to be saintly and non-sexual (Christ like). ${ }^{25}$ Ultimately, however, we are just substituting one poorly understood diagnosis (stigmata) with another (hysterical conversion).

The validity of the miracle theory depends primarily on your personal beliefs. But even if you consider it to be possible you then have to consider why God has done this in the past to some rather odd people, why He has imposed ecstasy as an indispensable condition, and why He gives it to people at the varying sites in the abdomen and chest and why in the palms and not the wrists. Furthermore, why should God give the stigmata preferentially to women?

Many attempts have been made to diagnose the stigmata as symptoms of illness without much success. The evidence does suggest, however, that psychological mechanisms play some part in their formation. Theologians seem equally baffled. Whatever your beliefs, the study of the stigmata does typify the fascinating relation between physical, psychological, and spiritual phenomena.

\title{
References
}

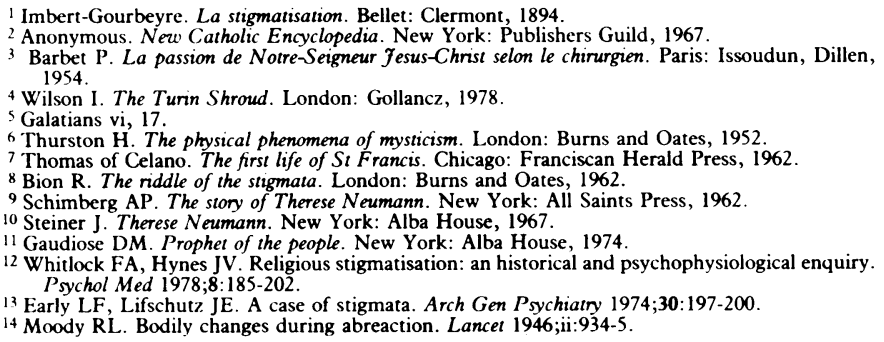

\section{Medical clergy: square pegs in holy holes?}

\author{
KEITH LEIPER
}

It was the first Sunday of my new life as a theological student. I had arrived at the parish church to which I was to be attached. The vicar, to put me at my ease, introduced me to a doctor who was a prominent member of his congregaton, who asked me what my job had been before I came to college. I replied that I had been a general practitioner. He looked at me in astonishment and exclaimed, "You must be mad!"

Nowadays many people make radical changes of direction in mid-life. Doctors have often played a part in the informal ministry of their local churches as deacons, lay preachers, or readers. When I was accepted for training for the Anglican ministry I tried to find other doctors who had either left the practice of medicine to become ministers or combined the roles of doctor and clergyman. I sent questionnaires to 68 medical clergy, and the following impressions are based on the 44 replies that I received.

\section{The typical medical clergyman}

As shown in this study the typical medical clergyman is in his 50s, probably an Anglican, and almost certainly married with children. He comes from a solidly middle class background: nine of the 44 respondents were sons of doctors, and nine sons of clergymen. He is likely to have grown up in a strongly churchgoing family, with close relatives working either in medicine or in the church. He probably formed the intention of becoming a doctor quite early in life, at about the age of 15 . Though the influence of the church might have been strong, his parents will have been the people who most shaped his choice of career. The example of

St John's College, Nottingham NG9 3 DS

KEITH LEIPER, MA, MB, theological student

Correspondence to: 55 Bridle Close, Ford, Bidston, Birkenhead L43 9UU. friends in the medical profession may well have influenced him; the advice of clergy and schoolteachers was usually less important.

The medical clergyman comes from a privileged educational background. Twenty nine respondents had attended public or independent schools, and only one had been to a comprehensive. $\mathrm{He}$ is most likely to have studied at a London medical school, often preceded by Oxbridge. (Cambridge gained a commanding lead over Oxford by 10 "mediclerics" to two.) Only five of the group entered theological college first and so entered medical school as ordained clergymen.

After qualification the medical clergymen had followed a wide range of careers in medicine. A third had worked abroad, either as missionaries or as government medical officers, and a similar proportion had acted as medical officers in the armed forces. Almost half had worked as general practitioners, while one in five had been a hospital consultant. Two of the doctors who had been ordained before entering medical school were still in junior posts in hospital medicine. Only one respondent was a psychiatrist. Between them the medical clergy had accumulated six MDs, and 12 were fellows of royal colleges.

The group was roughly equally divided into those who combined the roles of doctor and minister and those who had relinquished the practice of medicine altogether. Some missionary doctors, when family or political considerations had forced them to return to this country, had chosen that time to leave medicine and to concentrate on the pastoral ministry. Nine doctors had taken retirement from their career in the United Kingdom and had subsequently been ordained.

\section{Becoming and being a minister}

Eight doctors reported that they had thought about ordination early in their lives, in two cases before the age of 10 . The average medicleric applied for training as a minister at about the age of 45 , but there was a wide range. He received most encouragement in taking this step from friends already in the ordained ministry; 
wives, parents, and other relatives were also often mentioned as influences. Two doctors had been directly invited to assume the role of pastor to their congregations. Four doctors said that no one had influenced them, and two reported that the impulse "came from God alone."

None of the medical clergy had been forced to give up medicine for legal reasons, but one doctor reported that when he had become separated from his wife he had, with great regret, thought it necessary to relinquish his activities as a minister and to revert to being only a doctor. Another medical clergyman commented that trying to combine the roles of doctor and priest had made him ill; his solution had been to give up medicine.

The training received varied greatly. One respondent had undergone a full novitiate in the Jesuit order that lasted six years; another reported that he had received no formal theological training at all. The older entrants had studied for a shorter time and in a less formal manner than the younger men. The training was often found to be taxing, both mentally and emotionally, and some doctors found it difficult to think in a new idiom. Only seven of the group had emerged with either a master's or a bachelor's degree in theology, and 20 said that they held no formal theological qualification.

Most of the respondents worked as pastoral parish ministers, acting as preachers, teachers, and pastors to their congregations and as ministers of word and sacrament. Those who still practised medicine clearly saw their medical work as an extension of this ministry. Several doctors mentioned a particular interest in the healing work of the church, and two had acted as hospital chaplains. One doctor wrote: "I lead worship on alternate Sundays, and I do some psychotherapy. . . . I run a group for the chronic bereaved, and am getting together a scheme for visiting the acutely bereaved. . . . I take a discussion group and a confirmation class, and I deal with all the hauntings in the parish-eight ghosts in four years!"

\section{Advantages and disadvantages}

Having been a doctor was seen as a benefit by several medical clergy: "One has an insight into the whole person." "I feel myself to be a better doctor, a more complete priest." "The doctor is less shockable." "A bedside manner has already been acquired." "I conduct worship in church as a kind of group therapy." Clearly, though, there are also disadvantages: "The medical tendency to be brisk, brusque, dogmatic." "The urge to treat a problem medically, which I cannot now do. . . ." "Tensions arise between an 'achievement profession' and 'waiting on God.' ' Sometimes difficulties arose in the dual role: "I'm expected to give consultations in church-without my records." "People don't know whether to call me doctor or vicar." "Unless I'm careful I suffer from role confusion." And a final, and rather worldly, comment: "I got paid more as a part time doctor than as a full time priest."

My personal impression was that the medical clergy found their work deeply fulfilling. I asked for reactions from wives and families, and, though I received only a few replies, some tensions emerged. Wives seemed either to accept their husband's role and to identify strongly with it or to resent the emotional preoccupation that he had in his work. But this is of course true both of many clerical marriages and of many medical marriages: both the Church and medicine are well recognised as difficult vocations to which to be wedded.

\section{A double vocation?}

Medical clergymen are united by two strong links; the group identity of the medical profession, and a need to serve people in a mode that is different from the medical mode. In sociological terms those who give up medicine to enter the ministry are moving from one prestigious profession to another only a little lower in popular esteem. In economic terms they are taking a substantial reduction in salary. If there is such a thing as vocation this vocation is unusual.
It might be expected that those doctors who became clergymen would feel that, for them, medicine had been a diversion or a false start. One Catholic priest wrote, "Yes, perhaps 10 years of medicine were partially wasted-I could have been a priest that much earlier." But he, and almost all the group, thought that medicine had at the time been a true calling, which in time had been overtaken by a second and greater calling; and only five had ever seriously thought that becoming both doctor and minister had for them been a mistake.

Perhaps square pegs can sometimes be fitted into two different square holes. Perhaps being a doctor is quite a useful preparaton for the life of the minister. I, for one, hope so.

\section{MATERIA NON MEDICA}

\section{The more things change ...}

Pathologists have had many roles in hospital medicine and may develop others yet unforeseen in the future, but one that I have found fairly constant is trying to persuade clinicians (especially young ones) to give on the request form some relevant details of the case. From my present laboratory we refer a small proportion of requests to central reference laboratories and as a matter of courtesy I scrutinise such requests and

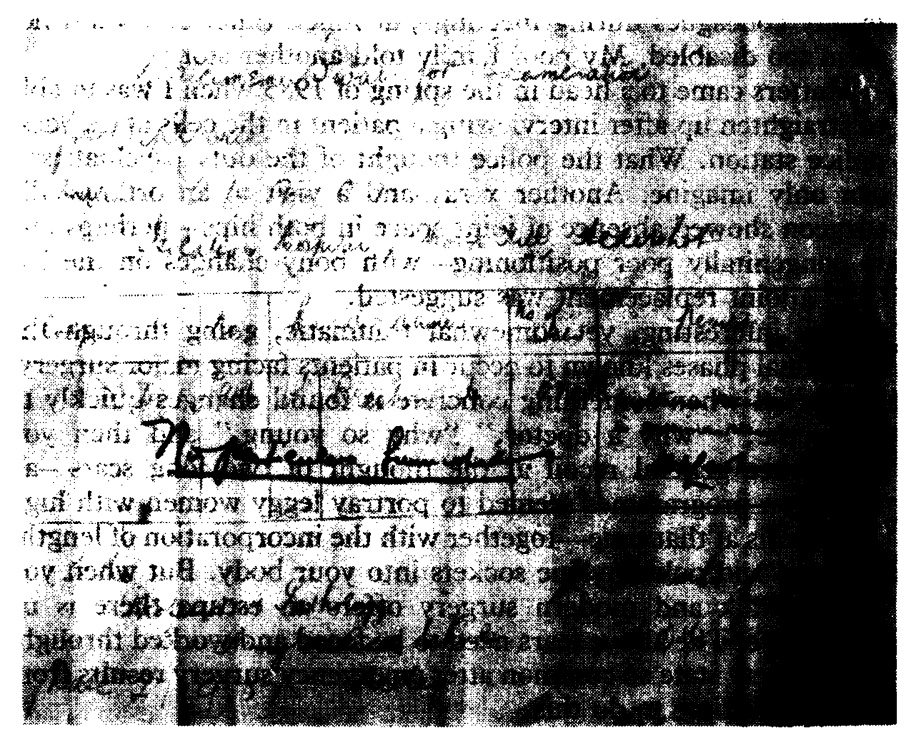

occasionally, when more irritable than usual, send one bouncing back to the junior clinician with the irascible scrawled insult over it. One gets a name for it.

When things get very bad my gaze wanders to a framed piece of paper over my desk. I work in a well known military hospital and my laboratory is named after a well known army pathologist. He also, more notably perhaps, gave his name to a haematological stain and an organism and disease still widespread in tropical climes. The piece of paper was found recently in the loft of a building in Aldershot which was, in 1901, the military isolation hospital. It is a contemporary laboratory request form and concerns a throat swab from a private soldier. It is addressed to the central military laboratory, then at Netley, and asks for culture reference diphtheria. The handwritten report which matches the signature states, "Diphtheria baccillus present in specimen received." It is signed W B Leishman, Major RAMC 27.09.01. In the same hand, but obviously affected by passion and slashed across the bulk of the form, are the words: "No particulars furnished." It never ends.-J G WINWICK, professor of army pathology. 